\title{
PEMBERDAYAAN EKONOMI MASYARAKAT DESA SARIBAYE MELALUI PENGOLAHAN ABON IKAN NILA
}

\author{
Embun Suryani ${ }^{* 1}$, , Lalu Muhammad Furkan ${ }^{1)}$, Diswandi $^{1)}$, Adi Septiawan ${ }^{1)}$, \\ Guswulandari $^{1)}$ \\ 1)Fakultas Ekonomi dan Bisnis, Universitas Mataram \\ Jalan Majapahit Nomor 62, Kota Mataram, Nusa Tenggara Barat \\ *)alamat korespondensi: embunsuryani@unram.ac.id
}

\begin{abstract}
ABSTRAK
Desa Saribaye terletak di Kecamatan Lingsar Kabupaten Lombok Barat. Desa ini memiliki potensi sumberdaya alam yang besar, salah satunya dari sektor perikanan. Jenis komoditas perikanan yang banyak dibudidaya masyarakat adalah ikan nila Oreochromis niloticus. Upaya peningkatan nilai tambah dari komoditas ikan nila sebagai bahan baku pengolahan produk pangan siap komersil belum banyak dilakukan. Pengolahan abon ikan nila merupakan salah satu upaya pengolahan abon dengan memanfaatkan ketersediaan bahan baku dan karakteristik bahan yang sesuai untuk pengolahan abon. Pengetahuan ibu-ibu rumah tangga Desa Saribaye tetang tata cara pembuatan, pemberian resep abon nila bercita rasa khas, dan pengemasan produk berstandar masih minim. Berdasarkan hal tersebut, kegiatan pengabdian kepada masyarakat ini bertujuan untuk memberikan pemahaman kepada masyarakat Desa Saribaye (ibu-ibu rumah rangga) mengenai tata cara pengolahan abon ikan nila dan pengemasan berstandar usaha; dan menciptakan peluang usaha baru untuk mendukung terbentuknya wanita yang berdaya dan kuat secara ekonomi maupun sosial. Metode yang dilakukan pada pengabdian ini adalah DEMPLOT (Demonstration Plot) dan diskusi mengenai produk olahan yang akan dibuat. Hasil dari kegiatan ini adalah ibu-ibu rumah tangga di Desa Saribaye memiliki ketrampilan dan pengetahuan untuk mengolah ikan nila menjadi abon ikan nila yang memiliki nilai ekonomis yang lebih tinggi dan memiliki cita rasa yang tinggi. Selain itu, melalui kegiatan ini tercipta produk olahan yang khas sehingga dapat menjadi produk oleh-oleh bagi wisatawan yang berkunjung ke Desa Saribaye. Keberlanjutan pemberdayaan ini dapat meningkatkan pendapatan masyarakat khusus perekonomian ibu-ibu rumah tangga melalui optimalisasi potensi lokal.
\end{abstract}

Kata Kunci : abon ikan nila, pengolahan ikan, desa saribaye 


\section{PENDAHULUAN}

Indonesia memiliki potensi perairan yang dapat mendukung potensi ekonomi, potensi pertahanan dan potensi persatuan bangsa. Dua pertiga luas wilayah Indonesia adalah lautan, sehingga memiliki potensi besar untuk perekonomian. Luasan lautan 5,4 juta km2, ZEE 2,7 juta km2 dan panjang pantai $95.181 \mathrm{~km}$ (World Resources Institute, 1998). Potensi areal perikanan di Nusa Tenggara Barat (NTB) adalah 8.586,8 Ha (DKP, 2008; DKP, 2013) untuk budidaya air tawar; 26.287,5 Ha untuk budidaya air payau (DKP, 2008), dan sebesar 59.368,83 Ha untuk budidaya air laut (DKP, 2008).

Kabupaten Lombok Barat sendiri sebagai kabupaten penyumbang ke dua terbesar di bidang hasil budidaya perikanan. Berdasarkan Data Statistik Perikanan Budidaya Provinsi Nusa Tenggara Barat tahun 2014, potensi areal lahan untuk budidaya perikanan Kabupaten Lombok Barat sendiri mencapai 4.500 $\mathrm{Ha}$, dengan potensi hasil produksi $36.116,16$ ton. Realisasi yang ada di lapangan Kabupaten Lombok Barat mampu memanfaatkan potensi lahan tersebut seluas $1.977,11 \mathrm{Ha}$ dengan total produksi $11.237,37$ ton atau $43,94 \%$ dari potensi hasil yang diharapkan. Lombok Barat memiliki desa unggulan sebagai penghasil komoditas perikanan. Salah satu desa tersebut adalah Desa Saribaye. Desa Saribaye memberikan sumbangan besar dalam segi produksi perikanan. Luas lahan untuk tambak perikanan yang dimiliki, seluas $0,0025 \mathrm{~km} 2$ dari 1,73 km2 total luas wilayah desa (RPJM Desa Saribaye, 2019).

Desa Saribaye desa kecil yang ada di Kecamatan Lingsar. Berdasarkan data Desa Saribaye tahun 2019, jumlah penduduk Desa Saribaye berjumlah 736 KK atau 2.294 orang. Mata pencarian penduduk desa sebagian besar adalah buruh, baik itu buruh tani ataupun buruh proyek. Pekerjaan sebagai buruh tidak memberikan jaminan untuk memperoleh pedapatan yang cukup untuk memenuhi kebutuhan hidupnya, terutama bagi kebutuhan ibu-ibu rumah tangga. Keadaan ini terlihat dari golongan prasejahtera dan sejahtera 1 yaitu sebesar 23\%, 51\% keluarga sejahtera 2 dan sisanya sebesar $26 \%$ tergolong keluarga sejahtera 3. Masyarakat Desa Saribaye ini, tidak hanya kaum lakilaki yang bertugas mencari nafkah, melainkan kaum perempuannya pun turut mengambil bagian dalam menopang ekonomi keluarga. Oleh karena itu, perlu adanya perberdayaan kaum perempuan atau ibu-ibu rumah tangga dalam mengoptimalisasi potensi lokal, 
dengan harapan adanya penguatan ekonomi keluarga.

Potensi perikanan ikan nila (Oreochromis niloticus) sebagai salah satu potensi unggulan desa perlu mendapatkan perhatian dan pembinaan secara serius, serta berkelajutan agar dapat menghasilkan produk yang berkualitas., apabila menginginkan penguatan ekonomi masyarakat desa. Untuk dapat menghasilkan produk olahan berbahan baku ikan nila yang dapat bersaing di pasaran perlu manajemen usaha yang profesional. Hal ini dapat terwujud jika komuditas ikan nila desa dijalankan oleh sumber daya manusia yang berkualitas mengingat komoditi ini rentan dalam hal kualitas dan pemasaran.

Selama ini, ikan nila di Desa Saribaye sebagian besar dipasarkan dalam bentuk utuh tanpa adanya olahan lanjutan untuk keperluan rumah makan, konsumsi rumah tangga, dan dll. Upaya untuk meningkatkan pemanfaatan ikan nila sebagai bahan baku pengolahan produk pangan yang siap konsumsi seperti abon belum banyak dilakukan.

Pengolahan abon ikan nila merupakan salah satu upaya diversifikasi pengolahan abon dengan memanfaatkan ketersediaan bahan baku dan karakteristik bahan yang sesuai untuk pengolahan abon. Penggunaan ikan nila pada pengolahan abon ini bertujuan untuk memberi cita rasa dengan sumber bahan alami dan optimalisasi potensi lokal. Sementara itu juga penggunaan ikan nila akan memberikan sumbangan gizi sebesar 17,5\% (Khairuman dan Amri, 2005), sedangkan untuk kandungan Karbohidrat 0,32 gram/100 gram daging ikan nila, protein 16,79 gram/ 100 gram, dan lemak 0,18 gram/100 gram. Penggunaan ikan nila ini tentunya mendukung dalam pemenuhan kebutuhan pangan sehat di pasaran.

Pengetahuan ibu-ibu rumah tangga Desa Saribaye tentang diversifikasi pangan bernilai komersil masih kurang, oleh sebab itu penggunaan potensi lokal ikan nila belum menjadi perhatian/ pemikiran dalam membuat abon bercita rasa khas untuk komersil. Pengetahuan ibu-ibu desa juga masih minim dalam hal pengemasan produk yang standar pasar.

Pemberdayaan yang pernah dilakukan bagi ibu-ibu rumah tangga di Desa Saribaye adalah pelatihan pembuatan abon ikan nila, namun pelatihan ini masih dalam tahap pembutan saja tanpa pengemasan produk, dan belum adanya komposisi jelas dalam hal cita rasa khas produk. Sehingga pada pengabdian 
sebelumnya mendapatkan hasil produk abon nila yang belum siap beredar di pasaran dalam rangka penguatan ekonomi ibu rumah tangga.

\section{METODE KEGIATAN}

Metode yang digunakan pada pelaksanaan pengabdian kepada masyarakat ini adalah Demontration Plot (DEMPOT). Demontration Plot adalah suatu metode pelatihan kepada masyarakat, dengan cara membuat objek percontohan agar masyarakat bias melihat dan membuktikan terhadap objek yang didemontrasikan (Irhan dalam Warnawasih, 2019).

Pemberdayaan ini diikuti oleh 12 orang yang tergabung di persatuan ibu PKK Desa Saribaye. Metode DEMPLOT ini memberikan rasa keterlibatan peserta dalam mengikuti kegiatan. Keterlibatan mereka dalam kegiatan pengabdian pada masyarakat ini dapat dilihat pada Tabel 1.

Tabel 1 Keterlibatan Khalayak Sasaran

\begin{tabular}{|c|c|c|}
\hline Kyalayak & Solusi & Target Luaran \\
\hline \multirow{7}{*}{$\begin{array}{l}\text { Ibu ibu rumah } \\
\text { tangga Desa } \\
\text { Saribaye }\end{array}$} & $\begin{array}{l}\text { - Demontrasi Plot mengenai tata } \\
\text { cara pembuatan abon dari }\end{array}$ & $\begin{array}{l}\text { - } \text { Meningkatkan } \\
\text { pemahaman }\end{array}$ \\
\hline & $\begin{array}{l}\text { persiapan bahan dan alat sampai } \\
\text { pengemasan olahan }\end{array}$ & $\begin{array}{l}\text { tentang pengolahan ikan } \\
\text { nila menjadi abon }\end{array}$ \\
\hline & $\begin{array}{l}\text { - Pengarahan mengenai pentingnya } \\
\text { nilai tambah potensi lokal ikan } \\
\text { nila menjadi abon }\end{array}$ & $\begin{array}{l}\text { - Adanya kesadaran dan } \\
\text { peningkatan pemahaman } \\
\text { mengenai tata cara dan }\end{array}$ \\
\hline & $\begin{array}{l}\text { - Mengaitkan potensi usaha } \\
\text { keberlanjutan abon nila terhadap }\end{array}$ & $\begin{array}{l}\text { pemberian kemasan pada } \\
\text { produk olahan }\end{array}$ \\
\hline & potensi penguatan ekonomi & - Adanya produk olahan \\
\hline & keluarga & abon nila siap \\
\hline & & komersialisasi di pasaran \\
\hline
\end{tabular}

$\begin{array}{ll}\text { Pelaksanaan pemberdayaan ini } & \text { 1. Persiapan bahan baku } \\ \text { dilakukan dengan beberapa } & \text { 2. Proses pengolahan olahan } \\ \text { tahapan, tahapan-tahapan yang } & \text { abon }\end{array}$

didemontrasikan sebagai berikut: 
3. Pengemasan sesuai standar pasaran

Model penyelesaian masalah yang diterapkan pada pengabdian kepada masyarakat ini, terlihat pada gambar 1 Bagan Skematis Metode Kegiatan.

\section{Permasalahan}

- Ibu-ibu Desa Saribaye kurang memahami pengolahan abon ikan nila.

- Ibu-ibu PKK kurang memahami keterkaitan optimaliasi potensi lokal terhadap penguatan ekonomi keluarga.

- Ibu-ibu PKK kurang terampil dalam mengolah ikan menjadi abon.

- Ibu-ibu PKK belum memahami konsep pengemasan produk olahan berstandar pasar

- Ibu-ibu desa kurang memahami manajemen keberlanjutan usaha.
Pemecahan Masalah

- Meningkatkan pengetahuan tentang ikan nila menjadi abon.

- Meningkatkan pengetahuan tentang keterkaitan optimaliasi potensi lokal terhadap penguatan ekonomi keluarga

- Meningkatkan keterampilan dalam mengolah abon menjadi produk komesialisasi yang berkualitas.

- Meningkatkan pemahaman tentang konsep pengemasan berstandar produk pasaran.

- Memberikan pemahaman mengenai manajemen usaha.

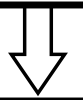

\section{Metode Kegiatan}

- Demonstration Plot mengani proses pembuatan abon ikan nila.

- Tanya jawab mengenai beberapa aspek tentang optimalisasi potensi lokal menjadi abon .

- Pelatihan pembuatan produk dari ikan nila menjadi abon beserta pengemasan berstandar

\section{Alternatif Pemecahan Masalah}

- Meningkatkan pemahaman ibuibu tentang pemanfaatan ikan nila menjadi produk abon bercita rasa khas dan berkualitas melalui Demonstration Plot, Tanya jawab, dan pelatihan pembuatan olahan ikan nila menjadi abon. 


\section{HASIL DAN PEMBAHASAN}

Permasalahan yang ditemukan pada survey di lapangan yakni para pembudidaya ikan nila ataupun masyarakat umum di Desa Saribaye menjual produksinya dalam bentuk produk basah (tanpa olahan) atau sebagai daerah yang memiliki potensi wisata setidaknya terdapat produk olahan potensi lokal ikan nila dan masyarakat Saribaye belum menangkap peluang ini untuk di komersialkan. Kegiatan pelatihan pengolahan abon ikan nila merupakan solusi terhadap pemecahan masalah tersebut dan kegiatan ini dilaksanakan pada tanggal 20 Agustus 2019. Ibu-ibu peserta pemberdayaan sangat antusias melaksanakan kegiatan ini, bahkan berharap kegiatan pelatihan ini dilakukan berkelanjutan sampai adanya izin usaha dan label halal dari MUI.

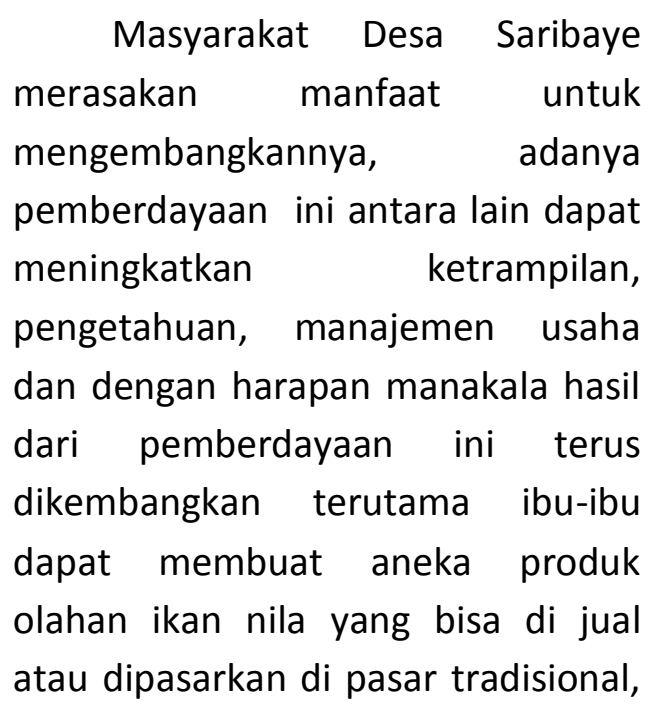

Available online : http://abdiinsani.unram.ac.id Doi article : http://doi.org/10.29303/abdiinsani.v6i3.280 pasar modern, dan yang berada di sepanjang pariwisata desa (kebun irup dan hutan irup). Produk olahan abon ikan nila yang khas ini dapat dijadikan sebagai daya tarik pengunjung / wisatawan untuk datang berlibur ke Desa Saribaye. Sehingga secara tidak langsung dapat meningkatkan pendapatan keluarga secara khusus dan perekonomian masyarakat secara umum.

Ikan nila yang digunakan dalam pembuatan abon adalah ikan nila segar dan ukuran besar yang telah dikukus kemudian suir sehingga berbentuk suiran kecil. Penggunaan ikan nila selain untuk memberikan cita rasa khas ikan darat juga memberikan tambahan kandungan gizi yang sangat banyak (Ramlah, 2017). Tektur abon ikan nila yang dihasilkan kegiatan ini memliki tekstur sama dengan abon lainnya.

Antusias masyarakat Desa Saribaye dalam pelatihan pembuatan bakso dari rumput laut terlihat pada Gambar 2.

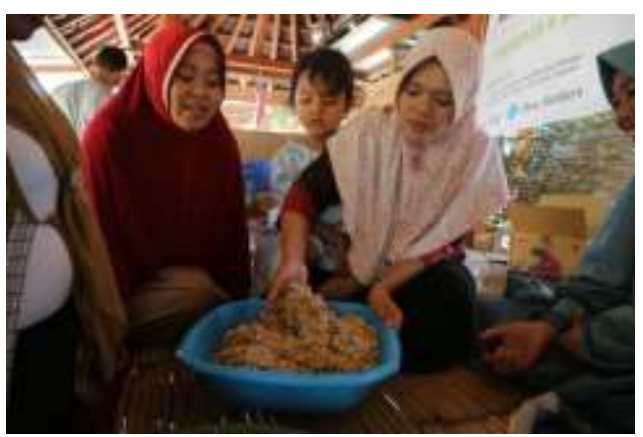

Gambar 2 Antusias Ibu-Ibu PKK 
Hasil wawancara singkat yang dilakukan kepada para ibu-ibu peserta pelatihan dapat menggambarkan beberapa hasil ataupun alasan mengapa masyarakat sampe saat ini belum memanfaatkan potensi ikan nila sebagai aneka produk olahan yang dapat menguatkan ekonomi keluarga. Adapun alasan tersebut adalah :

1. Tidak memahami tata proses pembuatan abon berstandar pasaran.

2. Tidak adanya pendampingan yang berkelanjutan dan monitoring berkala pada pelatihan yang sudah dilakukan.

3. Tidak pahamnya ibu-ibu mengenai manajemen usaha yang baik dan benar.

Adanya pelatihan tersebut dapat merubah pemikiran dan perhatian masyarakat, khususnya ibu-ibu rumah tangga dalam memanfaatkan potensi lokal ikan nila menjadi produk olahan (abon ikan nila). Berdasarkan hasil wawancara setelah pelatihan pembuatan, mengatakan bahwa adanya harapan keberlanjutan, akan memberikan inovasi baru, dan mulai menata optimalisasi potensi lokal daerah, terutama ikan nila. Ningsih et.al., (2019) menyatakan bahwa kegiatan pelatihan dapat meningkatkan pemahaman terhadap objek yang menjadi target materi kegiatan.

Hitung ekonomi yang dapat dihasilkan pada pembuatan abon ikan nila pada kegiatan pengabdian kepada mesyarakat ini sebagai berikut. Apabila menetapkan ikan nila pada posisi harga Rp30.000/1 $\mathrm{kg}$, maka total biaya bahan baku sebesar Rp450.000 untuk kapasitas produksi $10 \mathrm{~kg}$ ikan nila. Kuantitas yang dapat dihasilkan dari kapasitas produksi $10 \mathrm{~kg}$ ikan nila mencapai 4 kg abon ikan nila siap kemas. Per kemasan abon diisi dengan berat $100 \mathrm{gram} / \mathrm{sachet}$. Sehingga 4.000 gram : 100 gram dihasilkan 40 sachet. Harga jual dari abon nila ini sendiri bisa mencapai Rp25.000 s/d Rp30.000 per sachet. Keuntungan yang diproleh dalam olahan per 10 kg abon ikan nila adalah Rp550.000, dengan keuntungan tersebut belum dihitung biaya penyusutan peralatan yang digunakan.

Keuntungan yang didapatkan tentunya akan memberikan nilai tambah yang sangat luar biasa, apabila melakukan pengolahan lanjutan dari potensi lokal ikan nila yang dimiliki Desa Saribaye. Hasil dari pemberdayaan ibu-ibu rumah tangga dalam pengolahan potensi ikan nila menjadi abon ini seperti terlihat pada Gambar 3 abon dari ikan nila hasil dari kreasi mitra/PKK Desa Saribaye berupa abon yang siap komersil.

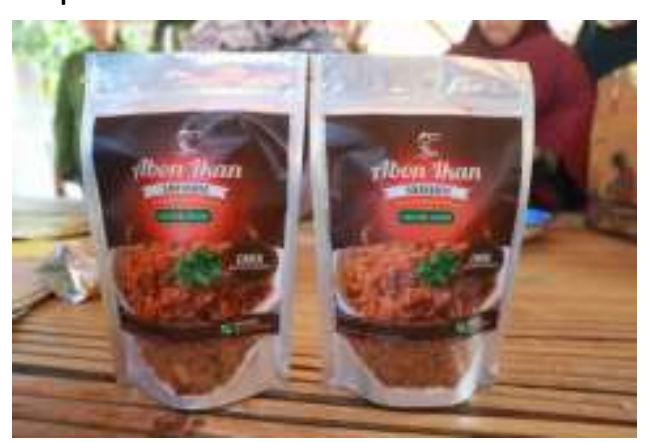

Gambar 3 Produk Olahan Abon 
Evaluasi dari kegiatan Desa Mitra ini diharapkan peserta pelatihan dapat memanfaatkan dan menguatkan ekonomi kelaurga, melalui potensi lokal yang ada di desa.

\section{KESIMPULAN DAN SARAN}

\section{Kesimpulan}

1. Ibu-ibu rumah tangga Desa Saribaye mampu mengolah abon ikan nila dengan cita rasa tinggi dan memiliki nilai jual yang tinggi pula.

2. Dengan bertambahnya ketrampilan tersebut menciptakan peluang usaha baru bagi ibu rumah tangga khususnya dan masyarakat Desa Saribaye umumnya. Selanjutnya, terbentuk wanita yang berdaya dan kuat secara ekonomi maupun sosial.

\section{Saran}

$$
\begin{aligned}
& \text { Saran yang dapat diberikan } \\
& \text { penulis untuk keberlanjutan } \\
& \text { program pengabdian kepada } \\
& \text { masyarakat ini : }
\end{aligned}
$$

1. Adanya pendampingan kepada ibu-ibu mengenai manajemen usaha lanjutan sampai mendapatkan izin MUI.

2. Adanya inovasi produk produk olahan lanjutan berbahan dasar ikan nila sebagai potensi lokal desa.

\section{DAFTAR PUSTAKA}

Dinas Kelautan dan Perikanan Provinsi NTB. 2008. Identifikasi Potensi Budidaya Air Tawar NTB Tahun 2008 [laporan kinerja lembaga]. Mataram: DKP Provinsi NTB.

Dinas Kelautan dan Perikanan Provinsi NTB. 2013. Identifikasi Potensi Budidaya Air Tawar NTB Tahun 2008 [laporan kinerja lembaga]. Mataram: DKP Provinsi NTB.

Ramlah R. 2017. Perbandingan Kandungan Gizi Ikan Nila Oreochromis niloticus Asal Danau Mawang Kabupaten Gowa Dan Danau Universitas Hasanuddin Kota Makassar. BIOMA: JURNAL BIOLOGI MAKASSAR 1.1.

Khairuman, Amri K. 2005. Budi Daya Ikan Nila Secara Intensif. Agro Media: Jogjakarta.

Ningsih, Novia, La Nalefo, and Wunawarsih IA. 2019. Efektivitas Metode Kelompok terhadap Peningkatan Pengetahuan Wanita Tani dalam Pemanfaatan Lahan Pekarangan di Desa Kalimas Kecamatan Kaledupa Kabupaten Wakatobi. Jurnal IImiah Membangun Desa dan Pertanian 4:2. 